\title{
Stort og smått
}

I de tidligere tidsskriftene var det ofte oversikter over ulike medisinske forhold rundt omkring i landet, gjerne basert på foredrag. I Tidsskriftet nr. 6/1925 gjennomgikk fylkeslegen i Hedmark stort og smått fra sitt fylke, herunder geografiske forhold, befolkning, tuberkulosearbeid og organisering av helsevesenet - der små enheter ble foretrukket fremfor store (Tidsskr nor Lægeforen 1925; 45: 313-25).

\section{Hygiene, social medicin, lageforhold m.v.}

Medicinalforholdene i Hedmark fylke 1924.

Foredrag paa D.n.l.f.s landsmøte i Hamar, august 1924. Av V. Hille, fylkeslæge i Hedmark.

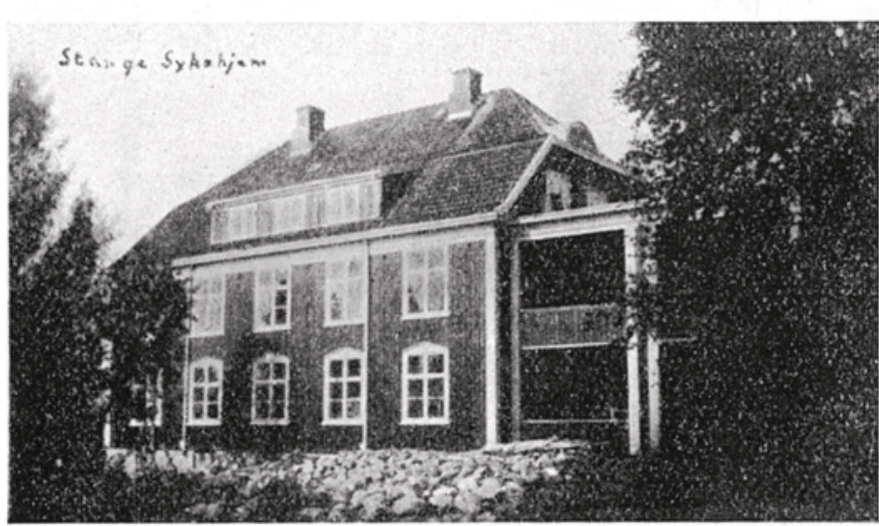

Stange sykehjem.

(...)

Antropologisk set er i Hedmark fogderi langskallene i overveiende flertal. I Østerdalen er der skille ved Tynset - søndenfor væsentlig langskaller, nordenfor kortskaller, i Solør en del indblanding av finsk blod. Klassemotsætningerne, som før var meget store, er efter hvert blit mindre. Smaabruksbevægelsen, som i socialhygienisk henseende er av ikke ringe betydning, har hat og har sterk vind i seilene. Der er megen nydyrkning, og der bygges hvert aar mange nye hjem.

De overordentlig store fremskridt i lægekunsten og det mægtige opsving i hygienen har hos os som ellers i den civiliserte verden fremtvunget en gjennemgripende forandring $\mathrm{i}$ de medicinale forhold. Mens mange av de herhen hørende spørsmaal allerede er løst i andre land, er vi kun langsomt kommet efter hos os. Det er ogsaa bemerkelsesværdig, at det social-hygieniske arbeid ikke har holdt skridt med utviklingen av mange andre samfundsforanstaltninger. I Hedmark fylke er det først i den aller siste tid, der er blit fart i det medicinale arbeid. (...)

Da trangen til sykehusbehandling i slutningen av forrige aarhundrede var stigende og der fra fylkeskommunens side ikke blev foretat

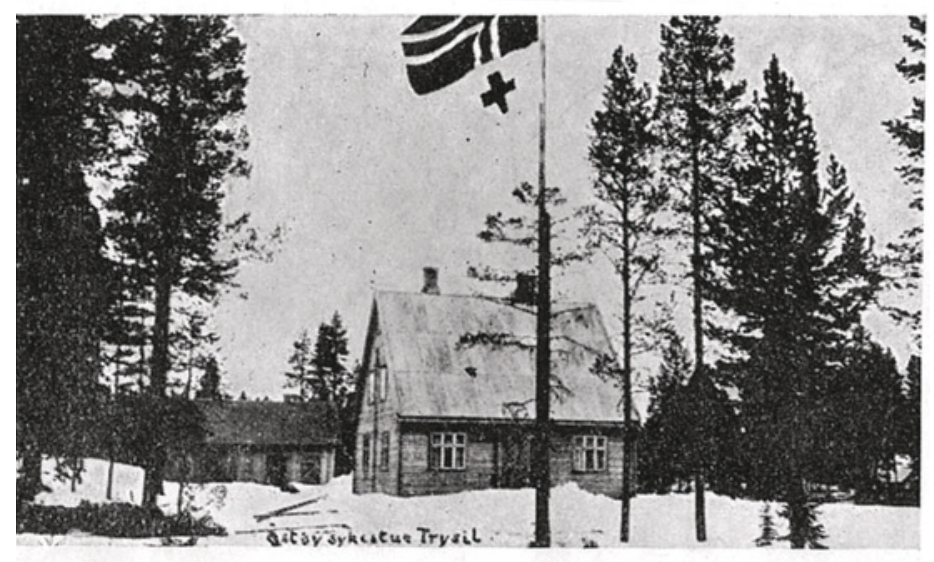

Østby sykestue, Trysil.

noget for at bedre sykehusforholdene, begyndte der omkring aaret 1900 en bevægelse for at faa opført s ma a sykehus rundt i bygderne. De første kom i stand væsentlig ved privat initiativ, senere traadte herredskommunerne til og tilsist fylkeskommunen. I 1915 var der i 11 herreder saadanne sykehus. De var fra først av særlig beregnet paa anbringelse av tuberkuløse; men der blev ogsaa behandlet andre syke - interne og kirurgiske. Denne bevægelse har i visse henseender lagt grundvolden for meget av det videre arbeid, specielt efter at fylket traadte støttende og ordnende til. (...)

De smaa kommunale sykehus har man forsøkt at gjøre saa hjemlige som mulig og vi kalder dem derfor ogsaa $i$ almindelighet s y k e h j e m. De er meget hensigtsmæssig indredet, malt med venlige farver, og utstyret er meget tiltalende - for de nyeste hjem tat fra Hedmark fylkes husflidskomité.(...)

Naar man i Hedmark fylke har gaat til en ordning som den nævnte med smaa sykehjem rundt $i$ bygderne istedenfor at ha et par store fylkessykehus, kommer dette av, at de vokset op likesom av sig selv - av en trang hos folket til sykehusbehandling. Fylkets store utstrækning og den forholdsvis spredte bebyggelse har ogsaa været en medvirkende aarsak. 